\title{
Indonesia Has It Backward: It's Not E-Cigarettes That's the Problem but Smoking
}

Lawrence O. Gostin

Georgetown University Law Center, gostin@law.georgetown.edu

http://www.oneillinstituteblog.org/indonesia-has-it-backward-its-not-e-cigarettes-thats-theproblem-but-smoking/

This paper can be downloaded free of charge from: https://scholarship.law.georgetown.edu/facpub/1488

http://ssrn.com/abstract=2618481

This open-access article is brought to you by the Georgetown Law Library. Posted with permission of the author. Follow this and additional works at: https://scholarship.law.georgetown.edu/facpub

Part of the Comparative and Foreign Law Commons, Constitutional Law Commons, Health Law and Policy Commons, Health Policy Commons, Public Health Commons, and the Public Policy Commons 
Indonesia recently announced that it will institute a nationwide ban on e-cigarettes. It might seem that banning an addictive and harmful, nicotine-delivering product that is attractive to kids makes sense. But it's a mistake. If Indonesia really wanted to protect kids and improve the public health, it would keep ecigarettes legal and use them effectively as a less-harmful alternative to smoking. Indonesia could strictly regulate e-cigarettes, such as making them safer, banning e-cigarette advertising that reaches children and banning their use (along with smoking) in public places. But banning e-cigarettes will make reducing smoking more difficult.

If there were no cigarettes or smoking, banning e-cigarettes would make good sense. But the main tobacco/nicotine public health problem facing the world today is smoking, and Indonesia has one of the world's highest rates of cigarette smoking. E-cigarettes should not divert policymakers attention away from implementing strong new measures to sharply reduce smoking and all the unnecessary death, disease, disability and economic costs caused by smoking.

Better yet, policy makers should recognize that e-cigarettes offer a useful tool for reducing smoking. Indeed, from a public health perspective, the only reason to allow e-cigarettes to be legally marketed and sold is to serve as an alternative source of nicotine for addicted smokers. Moreover, the availability of e-cigarettes as a smoking alternative opens the door to much more aggressive anti-smoking measures.

There are good ways to regulate e-cigarettes and their marketing to make them less harmful, to encourage their use as replacements for smoking, and to minimize the risk that their marketing will increase overall tobacco/ nicotine use and addiction. But the best way to get smokers to switch to ecigarettes would be to ban cigarettes and similarly smoked tobacco products (e.g., little cigars) or to minimize the nicotine in cigarettes and similarly smoked tobacco products so they no longer create or sustain nicotine addiction.

While there have been strong public health reasons for banning cigarettes for some time, it has not previously been seen as a viable policy option (except in tiny Bhutan, which has been tinkering with a comprehensive ban on tobacco products since 2004). Now, with e-cigarettes readily available, it should be much easier for many countries to design and implement effective cigarette bans, or at least minimize their nicotine levels. For example, countries that are concerned about losing cigarette tax revenues after a ban (despite the substantial economic benefits from reducing smoking) could still secure at least some replacement revenues through a new tax on e-cigarettes, whose sales would rise significantly after the cigarette ban.

In addition, Big Tobacco regularly blocks or delays effective tobacco control policies through exercising its enormous political and economic powers. But e-cigarettes make a cigarette ban more viable politically because companies that sell only e-cigarettes would welcome a cigarette ban, and ecigarettes offer the big tobacco companies, which sell both cigarettes and e-cigarettes, a way to stay in business after a ban (although with a smaller customer base). Many would argue, and we would agree, that the big tobacco companies do not deserve a viable economic future. But allowing them to survive by selling a much less harmful product to fewer people (ideally with strict restrictions on marketing and 
subject to other effective tobacco control regulations) might, in some countries, be necessary to implement a cigarette ban or other measures that will sharply reduce smoking.

More substantively, a major argument used against banning cigarettes or making them less satisfying to smokers has been the claim that doing so would prompt smokers to switch to illegal black market cigarettes. But e-cigarettes can offer smokers a legal, more readily available, less-harmful way to inhale nicotine that makes trying to find and obtain illicit black market cigarettes after a ban much less necessary or attractive. In fact, the Bhutan ban on tobacco products has prompted some illicit cigarette sales and not curtailed smoking as much as desired because it failed to leave addicted smokers with any readily available legal option for consuming nicotine without smoking (and allows cigarettes imports for personal use, which sustains continued smoking and provides cigarettes for illicit resale).

The idea that e-cigarettes now make banning cigarettes possible has recently been discussed as a valid policy option for China, and the same basic analysis can be applied to Indonesia and other countries, as well. Even without any cigarette ban, Indonesia and other countries could regulate e-cigarettes effectively to reduce smoking and overall tobacco and nicotine use harms.

By banning e-cigarettes, Indonesia has got it backwards and curtailed its ability to minimize smoking in the future. Banning any category of tobacco products is a commendable display of active tobacco control policy making. But Indonesia is directing its tobacco control policies at the wrong target. 